Бобан Трифуновић*

Универзитет у Београду

Филолошки факултет https://doi.org/10.18485/analiff.2020.32.2.2

821.111.09-32 Вилијамс Т.

Originalni naučni rad

Primljen: 15.07.2020

Prihvaćen: 11.09 .2020

\title{
ОЧАЈАЊЕ У СТАКЛЕНОЈ МЕНАЖЕРИЈИ ТЕНЕСИЈА ВИЛИЈАМСА
}

Рад ћемо посветити покушају да покажемо да је драма Стаклена менажерија Тенесија Вилијамса, у бити, драма очајања; да је драма у којој делање породице Вингфилд, готово у целости, условљава њихово очајање - што појединачно, што колективно. Држаћемо да је очајање породице Вингфилдових почело одласком г. Вингфилда, да кулминира у току драме и да је поново проживљено сећањем Тома Вингфилда. Да бисмо поткрепили своја тумачења, поћи ћемо од теоријских поставки Радомана Кордића, као и од одређених концепција Емила Сиорана. Такође, позваћемо се на рад Ериха Фрома и показати да је очајање Тома Вингфилда не само мотивација да поново проживи своја сећања, него и да потиче, добрим делом, од осујећења његових настојања да се самооствари као личност, кроз процес индивидуације.

Кључне речи: очајање, индивидуација, сећање, Емил Сиоран, Радоман Кордић, Ерих Фром.

Увод

У безнађу надражује његова добра утемељеност, његова очигледност, 〈документованост〉: оно је за репортажу. Испитајте, напротив, наду, њену издашност у лажи, њену манију да фабулира, њено одбијање догађаја: изметање, фикција. У том изметању је живот, из те фикције се он храни.

(Sioran 1998: 60)

У есеју насловљеном „Катастрофа успеха“, који је, као предговор, постао саставни део издања драме Стаклена менажерија 1987. године, Томас Ланир Вилијамс III (1911-1983) - познатији нам под псеудонимом Тенеси Вилијамс - навео је да му се ма које помињање

bob.trifunov@gmail.com 
успеха који је том драмом постигао, дословно, смучило. „Више нисам бивао поносан на свој комад“, навео је Вилијамс, „већ ми је постао одвратан. Вероватно због тога што сам се осећао тако беживотно да нисам био способан да напишем други. Ходао сам около мртав и знао да тренутно немам пријатеље које довољно познајем или им довољно верујем да бих могао да их одведем на страну и кажем им о чему се ради“ (Вилијамс 2002а: 8). Готово подједнако очајан, премда из других разлога, около је духовно и физички онемоћао газио и Тенесијев лик, Том, у Стакленој менажерији, такође без игде иког имало блиског коме би могао да повери ишта о својој патњи. Наравно, полазимо од претпоставке да Том очајава, да не жели да допусти нади - која, како је Емил Сиоран (1911-1995) написао, лаже и нуди фикцију наместо неприхватљивог стања ствари - да му, као Аманди, његовој мајци, замаже очи и помути перцепцију. Јасно, Амандина перцепција помућена је уверењем да ће се, сасвим сигурно, њена кћерка, Томова сестра, Лора, удати, упркос неколиким својим особинама - како физичким, тако и психичким - које томе, рекло би се, стоје на путу. Лорина удаја би, судећи према Амандиним прогнозама, требало да допринесе финансијској добробити породице - да, пре свега, Томова примања престану да буду једини извор прихода, међутим, Том је према тим очекивањима прилично подозрив. Притом, Том нипошто није једини од Вингфилдових који очајава; претпостављамо да очајавају он и његова сестра и мајка, разуме се, из различитих разлога.

У овом раду настојаћемо да покажемо за нашу претпоставку о очајању Вингфилдових, у драми, постоји озбиљно поткрепљење. Настојаћемо, наиме, да покажемо да је Тенесијева Стаклена менажерија драма у којој је преовлађујуће осећање - осећање очаја. У том маниру, посебну пажњу мораћемо да посветимо сваком појединачном, условно речено, случају очајања у породици Вингфилд, при чему ћемо се, свакако, бавити и г. Вингфилдом, чланом породице који је, истовремено, и (све)присутан и одсутан. Кад је о теорији реч, поћи ћемо од теоријских поставки које је, у свом делу под насловом Очајање, понудио Радоман Кордић (1937-). Консултоваћемо, уредно, и стваралаштво Емила Сиорана (на којег се Кордић, у својој монографији, позивао у прегршт наврата), будући да је он - како је казао румунски академик Еуђен Симион (1933-) - „даје нову реторику, реторику коју би требало да назовемо реториком агоније“ (Симион 2016: 143). Од помоћи 
ОЧАЈАЮЕ У СТАКЛЕНОЈ МЕНАЖЕРИЈИ ТЕНЕСИЈА ВИЛИЈАМСА

при покушају да протумачимо Тенесијеву драму биће нам и неколике психолошке поставке о процесу индивидуације Ериха Фрома (19001980), јер мишљења смо да управо овај процес има велики значај у драми, конкретно - у психологији у позадини лика, уједно и наратора у комаду, Тома Вингфилда. Коначно, кад је о циљу овог рада реч, могли бисмо да кажемо да ћемо, њиме, покушати да допринесемо даљем и подробнијем проучавању дела Тенесија Вилијамса, са посебним нагласком на драми захваљујући којој је постао познат и признат, али и књижевнотеоријских приступа који ће се засновати на филозофским и теоријским поставкама о очајању и патњи.

\section{Очајање Вингфилдових} очајања?

А који је пароксизам дубљи и органскији од пароксизма (Сиоран 2001: 22)

За очајање не постоји напред-назад, пре-после, ни покретност ни непокретност. Очајник пати од недостатка реалности. У очајању [...] све је у једном тренутку, у сваком тренутку. Нема редоследа. Све претпостоји. И ништа није.

(Kordić 2000: 196)

У опису ликова Стаклене менажерије, Вилијамс је пружио неке од најважнијих назнака које ће нам послужити да, што адекватније, проучимо његово дело и покушамо да га посматрамо кроз призму очајања. Најпре, Аманда Вингфилд описана је, између осталог, као „смушена жена која се грчевито држи за неко друго време и место“; притом, она сама није параноична ,али њен живот је параноја“ и ,зббог своје глупости понекад [je] несвесно окрутна“". Кад је о Лори реч, од ње је болест из детињства начинила „богаља, једна нога јој је мало краћа и има протезу“. Захваљујући томе, њена „изолованост расте до тачке на којој она постаје особа попут фигурица из њене стаклене колекције - сувише истанчана и крхка да би се померала са полице“. Напослетку, о Том је, напросто, описан као песник запослен на стоваришту, чија „природа није немилосрдна, али да би избегао замку он мора да поступа без милости“ (Vilijams 2002б: 13; курзив Б.Т.). Сâм Тенеси је, овом приликом, наговестио да постоји клопка из које ће 
Том имати прилику да се искобеља, под условом да, тада, буде немилосрдан, што, заправо, није у његовој природи. Напослетку, у опису прве сцене приказан је одсутни, а у Томовом сећању (све)присутни отац: „На зиду дневне собе, лево од лука, виси увеличана фотографија оца. То је лице веома лепог, младог човека са капом пешадинца из Првог светског рата [sic!]. Његов осмех је храбар и природан као да каже 'Увек ћу да се смешим'“ (Vilijams 2002б: 19).

Да би се очајање Вингфилдових ваљано објаснило, требало би почети од приповедачевог, Томовог, увода у први чин. Наиме, Том, каквог знамо из драме у целини, јесте песник. У складу с тим, он нас у први чин уводи на посебан, рекло би се, песнику својствен начин: „Да, у мојим џеповима су разни трикови, и још којешта у рукаву. Али, ја нисам мађионичар. Он вам пружа илузију која изгледа као истина. Ја пружам истину пријатно заогрнуту у илузију“ итд. (Vilijams 2002б: 20). Том јесте песник, али увод у драму, наравно, није морао да нам представи поетично; одабрао је да то, ипак, учини на тај начин. Његово очајање открило се публици, у суштини, већ тим чином. То, међутим, тренутно није најтранспарентније, али сигурни смо да ће постати пошто се позовемо на премису Емила Сиорана да је искуство патње „најозбиљније искуство после искуства смрти“, док склоност лиризму у „патњи значи остварити то унутрашње сагоревање и прочишћење, у којем ране престају да буду спољашње манифестације без дубоких компликација, већ учествују у сржи нашег бића“; другим речима: „Лиризам патње је песма крви, меса и нерава“ (Сиоран 2001: 7). Дакако, Томов очај би, прихватимо ли Сиоранову премису, био тек наговештен.

Наратор у драми је навео: „Овај комад је сећање“ (Vilijams 2002б: 20). Пођемо ли од чињенице да Том своју прошлост поново проживљава, да проживљава реминесценцију, могли бисмо да је поткрепимо тезом Радомана Кордића, према којој очајање „трансцендира егзистенцију“, чиме „човека оставља без икакве заштите“ (Kordić 2000: 193-194). Другим речима, Томово очајање, чији је извор смештен у прошлости, надишло је његову егзистенцију у садашњости и принудило га да, у оној мери у којој је то могуће, поново проживи поједине догађаје из прошлости, који су публици приказани као сцене. На тумачење ових околности дословно је применљиво Сиораново запажање које гласи: „У дубини памћења рађа се кајање“ (Sioran 
1989: 46). Јер, да посреди није нека потреба за кајањем, рекли бисмо потпомогнута очајањем, Том се не би одавао реминесценцији.

Овом приликом, не би било згорег нагласити да, како је приметила и Делма Е. Присли, Том своје сећање дели на тај начин да нас оно прогони; Пресли је приметила да Том, у своој завршном монологу, признаје да га је нешто походило (Presley 2007: 78). Мишљења смо да је посреди очај; да је очај, у бити, тај који га походи, надахнут немогућношћу да се помири са својим поступцима. Са̂м Том је о томе говорио на следећи начин: „Хтео сам да се зауставим, али нешто ме је прогањало. Увек је долазило ненадано, и хватало ме неспремног“ (Vilijams 20026: 89). Другим речима, уверени смо да очајање Тома, заиста, никада није напустило - упркос успеху на пољу индивидуације, о чему ћемо детаљније говорити касније.

Том је, такође, јасно нагласио да његово очајање није једино осећање које га, у тренутку приповедања, прожима: „Ја сам приповедач у комаду, а уједно и један од ликова. [...] Али, пошто имам песничку слабост према симболима, ја и овај лик користим као симбол; он представља закаснело, али вечито очекивано нешто због чега живимо“ (Vilijams 2002б: 20). У бити, Тома прожима и нада да ће очајање премостити; да ће поновним проживљавањем прошлости која је каналисана кроз његово сећање, моћи да поднесе то што је био принуђен да буде немилосрдан, да би - како је написао Тенеси Вилијамс - избегао замку.

У прилог нашој претпоставци да Том очајава, те и да је повод за његово очајање у прошлости, иде и чињеница да он у драму уврштава и свог оца - и то као лика (!), додуше одсутног: „Постоји и пети лик у комаду који се не појављује, осим на фотографији изнад камина, већој од природне величине. То је наш отац који нас је одавно напустио“(Vilijams 2002б: 20). О одласку оца бисмо, сасвим сигурно, могли да размишљамо као о праузроку не само Томовог, већ и очајања његове мајке и сестре, у односу на догађаје у драми којих се присећа. Одлазак оца назвали смо „праузроком“ искључиво из разлога што је породицу Вингфилдових он „одавно напустио“, при чему његов одлазак претходи и догађајима који су приказани у сценама - премда је извесно да су и они имали одређено трајање у прошлости, пре почетка саме драме. Наравно, од тренутка у којем се драма догађа свакако је знатно удаљенији одлазак оца, са којим породица не може да се 
помири, о чему сведочи његов увеличан портрет у дневној соби, али и константне алузије на њега и његове негдашње поступке. Кад је о очевој одсутности реч, покушаћемо да објаснимо зашто је он, заправо, (све)присутан, пошавши од ових Кордићевих постулата. Наиме, Кордић је навео да очајање „настаје на месту субјекта који не постоји - и у том субјекту“; такође, очајање је последица „настајања субјекта, ефекат онтологизације и уједно одговор субјекта који не постоји на ефекат настајања, на реалност коју он промовише“ (Kordić 2000: 71). Конкретно, Кордић је настојао да нагласи да непостојање субјекта производи очајање које ће заузети његово место, али и да ће недостајући субјекат бити поистовећен са очајањем.

У случају Стаклене менажерије, г. Вингфилд је изузет из живота своје породице, али је његово место заузело њихово очајање што их је напустио, које је, потом, почело да се поистовећује са њим самим. Притом, на г. Вингфилда је породица Вингфилд свакодневно подсећана захваљујући присуству његове фотографије у, претпостављамо, напрометнијој просторији у дому - што, такође, може да сведочи у корист могућности постојања мазохистичке потребе да на њега буду подсећани; односно, мазохистичке потребе да очајавају. У виду би требало имати да очајање и тенденција за повређивањем иду mano a mano, на шта је, на следећи начин, указао Кордић: „Очајање је садизам озлојеђених душа. Оно је и мазохизам тих душа, оно је увек садомазохизам“ (Kordić 2000: 215).

Продужићемо, потом, на лика који, како се чини, пружа основ за актуелно очајање Вингфилдових. Реч је, дакако, о Лори, која - сложили бисмо се са Бертом Кардулом - „представља категорију особе према којој су романтичари раног деветнаестог века осећали нарочиту наклоност: рањив, готово неземаљски его затиран животом у индустри-јализованим, пренасељеним, обезличеним градовима света на Западу“ (Cardullo 2007: 65). Лора сама по себи, онако како ју је Вилијамс описао, не делује као икакав изазивач очајања per se. Међутим, очајање происходи из чињенице да Лора има потешкоће са прилагођавањем спољашњем свету; из чињенице да јој не полази за руком да се уда - делом и због тога што она, активно, и не суделује у покушајима да пронађе себи супруга. Њена мајка, Аманда, уверена је да ће се супруг, тек тако, појавити - баш као што је, у њеној младости, у прошлости, у Плавој планини, на југу САД, у једном дану, дочекала 
ОЧАЈАЮЕ У СТАКЛЕНОЈ МЕНАЖЕРИЈИ ТЕНЕСИЈА ВИЛИЈАМСА

чак седамнаест просаца. Причу о својих седамнаест просаца причала је у неколико наврата, из чега је, такође, евидентан очај за који је заслужан г. Вингфилд.

Сама Лора је, свакако, свесна свог, условно речено, хендикепа; о самој себи мисли као о богаљу који нема готово никаквих изгледа да буде прихваћен у друштву тог времена у ширем смислу, а камоли у ужем, у „основној ћелији друштва““, као нечији супружник. Амандина перспектива на то је, пак, дисторзирана, махом јер она није у стању да о стварима размишља мимо схватања својствених сопственом времену и друштвеном и културном контексту из млађих дана; Аманда, напросто, није у стању да се помири са помишљу да се њена кћерка, због својих физичких и психичких особина, неће удати.

АМАНДА: Буди свежа и лепа! Још мало па је време да почну да стижу младићи. (Жустро, девојачким кораком оде у кухињицу) Шта мислиш, колико ће их данас доћи?

(Том баци новине на под, поскочи и јаукне)

ЛОРА (сама у дневној соби): Не верујем, мајко, да ће ико да нам дође.

АМАНДА (враћајући се, безбрижно): Шта? Нико... баш нико? Мора да се шалиш? [...] Ни један једини млади господин? То је немогуће! Биће то права навала, као кад протутњи торнадо!

ЛОРА: Никаква навала, мајко, и никакав торнадо. Ја једноставно нисам тако популарна као ти некада у Плавој планини... (Vilijams 2002б: 24)

Уколико би се Аманда помирила са помишљу да ће јој кћерка остати уседелица, морала би да прихвати и помисао да ће породица финансијски, дословно, пропасти, будући да не могу да се издржавају искључиво од Томових примања. Из тог разлога, али примарно због тога што је г. Вингфилд напустио породицу, Аманда је похођена очајем. Но, њеном очају ћемо се посветити пошто се позабавимо Лориним.

Колико смо имали прилику да приметимо, Лору је Вилијамс замислио као прилично стидљивог лика који се не да̂ уклопити у друштвени живот тог времена. Наиме, Лора је напустила Рубикамову пословну школу, коју ју је мајка приволела да почне да похађа. Такође, Лора нема пријатеље, ни пријатељице, нити је из ма којег њеног 
ретка текса евидентно да она жели да их стекне. Наместо људи, млада жена је умногоме посвећена својој колекцији фигурица од стакла, коју Аманда назива „стакленом менажеријом“. Јасно је да је њена колекција симбол њене крхкости; њене могућности да се сломи и под најмањим притиском. Кад је реч о овом конкретном симболу, могли бисмо да се сложимо са Харолдом Блумом, да је „приказ сломљеног или напуклог стакла - средишњи симбол овог комада, и без сумње прикладан симбол сломљене породице Вингфилд“ (Bloom 2007: 25).

Могло би се рећи да је породицу Вингфилд сломио неки немили догађај из прошлости - највероватније, одлазак г. Вингфилда. Уколико прихватимо да је лом одавно наступио, могли бисмо да постулирамо да су друштвене околности у које публика, заправо, има увид ништа до онога што је од породице Вингфилд преостало. Аманда, дошли смо, коначно, и до њеног лика, очајнички покушава да породицу, како-тако, одржи на окупу и помогне јој да издржи тренутне недаће. ${ }^{1}$ Аманда је дубоко уверена да ће њени напори да подучи Тома лепим манирима, да школује Лору, кад-тад, уродити плодом - да ће од Тома начинити озбиљног младог човека који ће, једног дана, моћи да ради пристојан посао, а од Лоре жену која ће бити образована, ако ce, већ, неће удати. Међутим, Амандини напори су готово узалудни, јер њен приступ је, чини се, потпуно погрешан. Наиме, њене референтне тачке су, искључиво, позициониране у прошлости; похрањене у догађајима које је проживела и из којих је имала прилику да извуче поуку. Захваљујући протоку времена и њеном пресељењу подаље од

1 У неком наредном раду, могли бисмо да пођемо од појединих психоаналитичких поставки и покушамо да протумачимо Амандино понашање не као исход њених покушаја да породицу одржи на окупу, већ да је још више распарча. Наиме, није немогуће да су бројни наизглед добронамерни савети упућени Тому, заправо, намерне провокације које ће га навести да, коначно, попут оца, напусти породицу што је, напослетку, и учинио. Из сцене у сцену, очигледно је да скоро сваку Амандину опаску доживљава као отров, а не мелем. Можда је Аманди немогуће да се носи са чињеницом да ју је супруг напустио, а да је Том, истински, подсећа на њега, што јој онемогућава да се помири са одласком г. Вингфилда. Овакве претпоставке поткрепљују неколике алузије на сличност између Тома и његовог оца или, пак, између склоности које Аманда претпоставља да Том има, а које је имао и његов отац (алкохолизам, посећивање куплераја или коцкарница ноћу и сл.). Томовим коначним одласком, Аманда би била остављена сама са Лором - која би, према њеној процени, кад-тад требало да се уда и, тиме, оде од ње; и тиме је остави саму, без деце, без подсетника̂ на свог супруга. 
Плаве планине, све њене по(р)уке су а priori промашене, јер нису у стању да се приближе околностима у којима се, сада, друштво налази, а тиме и чланови њене породице. Примера ради, Аманда је сигурна да ће, сваког часа, просци похрлити да куцају на њихова врата и, од ње, траже Лорину руку, упркос њеним физичким и психичким особинама. Нарочито након што је Лора напустила Рубикамову пословну школу.

TOM: После неуспеха у Рубикамовој пословној школи, мајци је у њеним рачуницама постајала све важнија и важнија идеја да се Лори нађе младић. Опседала ју је. Као неки архетип колективно несвесног, слика младића који долази у посету прогањала нас је по нашем станчићу... [...] Ретко које вече у кући могло је да прође без неке алузије на ову слику, ову приказу, наду... И када се младић не би помињао, његово присуство висило је у мајчином забринутом погледу и у бојажљивом и помирљивом сестрином понашању...

Нема сумње да је Аманда, из очајања, суштински, незадовољна својим, али и животима своје деце. Претпостављамо да она, напросто, није у стању да своје очајање обузда, те га поваздан манифестује на различите начине - најчешће посредством својих опаски, своје бриге и за најтривијалније ситнице свакодневице и сл.

АМАНДА: Шта ћемо да радимо, шта ће бити с нама, каква нам је будућност? [...] И шта нам сад преостаје у животу? Да седимо у кући и гледамо свечане поворке како пролазе? Играмо се стакленом менажеријом, зар не, драга? Да вечно вртимо те излизане плоче које је твој отац оставио као болну успомену на себе? Неће бити пословне каријере - од тога се одустало зато што ствара нервозу у стомаку! (Уморно се насмеје) Шта ти је остало сем да зависиш од некога целога живота? Ја врло добро знам шта се дешава са неудатим женама које нису спремне да се запосле. Видела сам ја на Југу такве жалосне случајеве... (Vilijams 2002б: 26; 28)

Очајање је, како је то Сиоран казао, „повређена таштина воље у борби са светом“ (Sioran 1989: 19). У Стакленој менажерији, то је најевидентније у Амандином опхођењу и перцепцији света и свега. Притом, из њеног очајања (конкретно због тога што је г. Вингфилд на- 
пустио породицу - нпр. његове излизане плоче су, још, „болна успомена") да̂ се приметити и да је Кордић био у праву када је констатовао да неко може да очајава „зато што није вољен [...] или због потребе да воли“" (Kordić 2000: 70). Теза о очајању из потребе да се буде вољен могла би се применити и на Тома и на Лору, јер њих је напустио отац. С друге стране, у комаду нема индиција да Том или Лора очајавају због тренутне оскудице љубави у својим животима - изузев уколико се као потреба за љубављу не протумачи то што је Том, из библиотеке, позајмио неко од дела Д. Х. Лоренса (1885-1930) - вероватно, роман Љубавник лејди Четерли (1928) или, мање вероватно, роман Синови и љубавници (1913), у којем (посвети ли се пажња психолошкој димензији дела) је посреди покушај сина да се удаљи од мајке - што, није немогуће, нипошто није нешто што би Аманда желела, али чега се, сасвим сигурно, прибојева.

Пошто смо понудили начелно појашњење очајања сваког од одабраних ликова Вилијамсове Стаклене менажерије, могли бисмо да се сложимо са Брендом Марфи и тврдимо да је сваки од ликова ове драме „на неки начин заробљен, и сваки је пронашао неки начин да побегне, при чему је најуспешнији био насмешени отац“" (Murphy 2014: 57). Том је заточеник обавезе према породици, због које је принуђен да ради на стоваришту; притом, не делује да ико из породице има имало разумевања за његово песништво или довољно обзира према његовој потреби за приватношћу - алудирамо, конкретно, на Амандину знатижељу у погледу ноћи које Том, већим делом, не проводи код куће, као и на њено згражавање и враћање књиге коју је читао у библиотеку (уп. Murphy 2014: 58-59). Лора је заточеник својих страхова и зазора према спољашњем свету, али и братовљеве и мајчине добре воље да се о њој старају, па и пошто на видело изађе да је напустила пословну школу. Аманда је, пак, заточеник своје прошлости, губитка свог супруга, али и бојазни за (пре свега, финансијску) добробит породице - чији је једини „спас“ прижељкивана Лорина удаја, односно долазак просаца. ${ }^{2}$ Међутим, Вингфилдови су, скупа,

2 Што се доласка просца, или више њих, тиче, јасно је да је реч о пукој фикцији. Аманда непоколебљиво верује да ће просци, заиста, доћи - да ће избавити њену породицу из свеопштег очајања. Кључна реч је, без сумње, „избављење“. Могли бисмо да се сложимо са Кардуловим мишљењем да Аманда очекује да ће долазак просца, једног или више, „пружити један вид религијског, политичког или егзистен- 
ОЧАЈАЮЕ У СТАКЛЕНОЈ МЕНАЖЕРИЈИ ТЕНЕСИЈА ВИЛИЈАМСА

осујећени својим очајањем из којег не могу да се искобељају, а то очајање, на неки начин, јесте и жалост. У том смислу, могли бисмо да се сложимо са становиштем Баруха де Спинозе (1632-1677) о жалости, које је изложио својој Етици - жалост је зло, а нарочито жалост која стоји на путу задовољењу жеље (Spinoza 1959: 29). Очај је Вингфилдове, дословно, сасвим скрхао: као што је приметио Том Скенлен, „породична хармонија сведена је на плитке усрдне чинове“, што може да нас доведе до закључка да је са̂м Вилијамс „незадовољан самим условима постојања (који су оличени у породичном животу и замисли о породици)“ (Scanlan 2007: 82).

Вратимо се, сада, очајању Тома Вингфилда. Детаљније образложење његовог очајања изискује позивање на филозофску концепцију Серена Кјеркегора (1813-1855) и психолошки појам индивидуације Ериха Фрома. Најпре, поћи ћемо од Кјеркегоровог постулата да је образац сваког очајања, у бити, „очајнички желети да се човек ослободи самога себе“" (Kierkegaard 1974: 16). Од чега, тачно, то Том жели да се ослободи? Као што смо казали у неком од претходних пасуса, Том је заточеник те, као и сваки заточеник, настоји да се ослободи својих окова, али и сопства које је било заточено; које је очајавало, жалило, жудело за слободом. Овај процес, који Кјеркегор назива ослобођењем, довели бисмо у везу са процесом индивидуације, који Фром одређује као „процес јачања и интеграције личности појединца“, у којем до одвајања од оних са којима је остварено првобитно јединство, што „може довести до изолације сличне потиштености и изазвати снажну стрепњу и несигурност“ (From 2016: 31). Притом, из вида не треба губити да прогрес индивидуације и личног Ја „зависи од појединца, али суштински зависи од друштвених услова“ (From 2016: 30).

Том, дакле, настоји да напредује на пољу индивидуације: пише песме, чита књиге, размишља о могућностима да постане трговачки морнар и сл. Другим речима, доказује себи да је способан за много тога, да ствара - како уметност, тако и новац; доказује себи да је могуће да се самооствари. Наравно, то му, никако, не полази за руком пре свега, због опструкција пореклом из породице; понајвише, Амандиних опструкција, што исходује његовим очајањем.

цијалног избављења и ослободити оне који чекају“ (Cardullo 2007: 71). Долазак је, дакле, више од пуког друштвеног догађаја, јер - према свом значају - далеко надилази сферу друштвеног и залази у сферу смисла егзистенције. 
Бобан Трифуновић

TOM: Гледај!... Немам ништа, баш ништа... [...] у животу, у овој кући, за шта могу да кажем да је моје! Све је... [...] Јуче си ми конфисковала књигу! [...] Кућа, кућа! Ко овде плаћа кирију, ко се преворио у роба да би... [...] Не, не, ја не смем ништа да кажем! [...] Не желим више ништа да чујем!

$[\ldots]$

АМАНДА: Слушаћеш, и доста је било увреда! Стрпљење ми је на крају!

TOM: А шта мислиш како је мени? Зар не би могло, мајко, да и моје стрпљење има крај? Знам, знам. То теби није важно, шта ја радим... шта ја желим да радим... (Vilijams 20026: 32-33)

Томов пример нам, несумњиво, показује да се људско искуство, у ширем смислу, налази „у стању сталне и неизбежне неравнотеже“, као и да човек не може „“живети” понављањем образаца врсте“; укратко, како каже Ерих Фром, човек „мора да живи“, јер је ,једина животиња за коју је сопствено постојање проблем који мора да реши и од којег не може да побегне“ (From 2018: 37). Из сцене у сцену, публика има прилику да присуствује Томовим неуспелим покушајима да реши проблем свог постојања; да се отргне очајању, прво, због одласка оца у детињству, а потом и због околности које су настале у периоду када је Аманда увидела да је Лора у годинама у којим је била и она сама када су просци почели да пристижу, те да би ваљало удати је што пре не би ли се, тиме, разрешиле њихове финансијске потешкоће.

Томов очај је, напослетку, надвладао његово осећање дужности према породици, што бисмо могли да посматрамо из Фромове перспективе. Како је Фром казао, свако „покушава да обнови јединство и равнотежу свега у мисли, изграђујући свеобухватну менталну слику света која служи као референтни оквир из којег може извући одговор на питање где се налази и шта треба да уради“ (From 2018: 41). Кад је о референтном оквиру реч, појединцу је референтни оквир друштво, а „друштво се може назвати неуротичним у смислу да су његови чланови осакаћени у развоју личности“; односно, устројство друштва је „противно људској срећи и самоостварењу“ (From 2016: 99). Томов референтни оквир је његова породица, а он у том референтном оквиру очајава; тај референтни оквир дисторзиран је у односу на спољашњи свет какав се њему приказује. Примера ради, Аманда непрестано алудира на 
догађаје и запажања из прошлости (да је у Плавој планини била популарна; да је г. Вингфилд био алкохоличар), препричава их и, на основу њих, предвиђа будуће догађаје (рецимо, да ће Том постати алкохоличар попут свог оца). Увидевши да је дисторзија у референтном оквиру неподношљива, да омета његове покушаје да се препусти индивидуацији, Том је одлучио да да̂ прилику ослобођењу од очаја, што је очигледно из његовог разговора са колегом са стоваришта, Џимом О'Конором, у шестој сцени, који га, по свему судећи, не схвата озбиљно:

ТОМ: Нећу бити овде.

ЏИМ: А твоја мајка?

TOM: Ја сам као мој отац. Покварени син поквареног оца! Да ли си приметио како се смешка на оној тамо слици? А нема га већ шеснаест година!

ЏИМ: Само причаш, давежу. Шта твоја мајка мисли о томе?

TOM: Шшшш! Ево је долази. Мајка није упозната са мојим плановима! (Vilijams 2002б: 64)

Могли бисмо, с друге стране, да приступимо Томовом поступку и из Сиоранове перспективе. „У стварности“, закључио је Сиоран, „све се своди на то да знаш је ли [живот, Б.Т.] подношљив или није. Проблеми престају и почињу одлуке“ (Sioran 1989: 44). У том смислу, могли бисмо да будемо мишљења и да је Том, напросто, донео одлуку на основу разине подношљивости своје свакодневице - и решио да нешто по том питању предузме, па било то и поистовећивање са чином који је, сасвим сигурно, још као дете, почео да презире; са чином одласка (од породице). И из ове перспективе, и даље је Томов очај тај који је његов свакодневни живот учинио неподношљивим. „Патња отвара очи, помаже нам да видимо ствари које иначе не бисмо запазили“, запазио је Сиоран и, потом, овај постулат преточио у форму попут картезијанске: „Патио је, дакле, схватио је“ (Сиоран 1999: 126). Еклатантан пример Томовог схватања јесте тренутак у којем га је Џим упозорио да би, на послу, требало да се „пробуди“, не би ли, тиме, одузео шефу повод да му да̂ отказ.

ЏИМ: Избациће те са посла ако се не пробудиш.

ТОМ: Будим се... 
ЏИМ: Не показујеш никакве знаке.

TOМ: Знаци су унутрашњи (Vilijams 2002б: 62).

Познато нам је, од самог почетка драме, да Тому није најпријатније што поново проживљава догађаје из своје младости - претежно догађаје у којима се осећао нелагодно, у којима је био бесан, у којима је сматрао да је израбљиван а да, притом, заузврат, није добио нимало разумевања. Тому за руком јесте пошло да напусти породицу, али он, како смо у прилици да посведочимо са самог краја драме, и даље очајава; и даље га прогони сећање на све што се догодило, али и извесно кајање што је Лору препустио самој себи, препустио њиховој мајци. То нам, несумњиво, показује да је Кордић у потпуности био у праву када је казао да „задовољена жеља може да буде узрок очајања“ (Kordić 2000: 30). Наиме, напустивши породицу, Том је себе ослободио од очајања које је стајало између њега и индивидуације. Међутим, он је увидео да, упркос индивидуацији, не може да се отресе очајања због своје сестре која је, врло вероватно, ужасно унесрећена његовим одласком. Притом, Томов одлазак је, претпостављамо, додао још соли на њену рану, коју је направио Џим О'Конор, одступивши од ње и рекваши јој да је обећан другој. Последица О'Коноровог одбијања и, потом, одласка, према Кардуловом постулату, јесте да „ниједан просац више никада неће ступити у њен живот; ниједан материјализмом задојен Американац неће бити тако осетљив да појми њену унутарњу лепоту, да цени њену љубав према лепоти, да схвати њену неприродну, ако не натприродну, улогу у свету којим господаре наука и технологија уместо срца и душе“" (Cardullo 2007: 73-74).

\section{Завршна разматрања}

Само у љубави се може видети колико си пропао.

(Сиоран 2001: 80)

Породицу Вингфилдових је, у Томовом сећању, походило очајање - чије је семе посејано још давним позивом г. Вингфилду, телефонисти, од далеких крајева, којем се одазвао и, тиме, напустио своју супругу и децу. Очајање је, онолико колико се из нараторовог сећања да̂ приметити, почело да букти када је Лора, како се то каже, стасала за удају. Очајање је пустило корење у свим нивоима породичног живота и почело да прети да ће га сасвим преузети. Том је надирућем очајању 
одолевао, претпостављамо из љубави према сестри и мајци. Међутим, љубав, сама по себи, није могла да издржи притисак избезумљујуће свакодневице, у којој је махом он био тај на којем се очај испољавао у свој својој силини. Очајање је читавој породици, тек тако, преузело стварност и заменило је сопственом. Сиоран је то изразио на следећи начин: „...свака јака патња ствара привид пуноће и нуди свести стравичну стварност, од које она не уме да утекне“ (Sioran 2004: 19).

У раду смо посебну пажњу посветили механици очајања и покушали да покажемо да очајање, у бити, руководи читавим Вилијамсовим комадом - од прве до последње сцене. Оно се, заправо, очитава већ у самој структури драме, а то је структура сећања - и то сећања на нарочито болне тренутке у животу Тома Вингфилда. Бренда Марфи је написала да је Стаклена менажерија „комад који је од субјективног доживљаја сећања начинио естетски приступ истини“ (Murphy 2014: 59). Истина би, у контексту нашег покушаја посматрања драме кроз призму очајања, била само Очајање. Другим речима, могли бисмо, у сиорановском духу, да кажемо да је Стаклена менажерија комад у којем се, у позадини личног искуства сећања, крије очајање као непокренути покретач сећања. Јер, мишљења смо, да Том није очајавао, не би се ни одао реминесценцији, која је кулминирала његовим поновним покушајем да се опрости од Лоре - односно, од сећања на Лору; од љубави према Лори.

Тенеси Вилијамс је, без сумње, успео да напише невероватно сложену драму; драму која је подложна вишеструким тумачењима, којима се, ни данас, шездесетпет година од првог публиковања, не назире крај. Нашим тумачењем, из перспективе поимања очајања онаквог о каквом су о њему, пре свега, писали Емил Сиоран и Радоман Кордић - допринели смо том тешко сагледљивом скупу тумачења, настојавши да се не утемељимо на конвенционалним теоријским приступима (нпр. психоанализа, феминизам, нови историзам), већ на приступу који је релативно мало, или нимало, заступљен на нашој академској сцени. Додуше, ништа мање од онога колико су и, рецимо, заступљена проучавања живота и дела Емила Сиорана. Надамо се да смо, овим радом, допринели досадашњим истраживањима стваралаштва Тенесија Вилијамса, као и да ћемо, њиме, подстаћи даља проучавања која су усредсређена на „стања душе“ каква су очајање и патња, пре свега, због релативне неистражености ових феномена у 
Бобан Трифуновић

науци о књижевности, а потом и да би се, сасвим сигурно, понудила примеренија тумачења значајних књижевних дела, какво је и Стаклена менажерија.

\section{ЛИТЕРАТУРА}

Bloom, Harold. (2007). "Introduction”, Bloom's Guides: The Glass Menagerie. Harold Blood Ed. Infobase Publishing, 7-47.

Vilijams, Tenesi. (2002a). „Катастрофа успеха“, Staklena menažerija. Beograd: NNK International, 7-11.

Vilijams, Tenesi. (2002б). Staklena menažerija. Beograd: NNK International.

Presley, Delma E. (2007). „Delma E. Presley On the Glass Menagerie as American Memory“", Bloom's Guides: The Glass Menagerie. Harold Blood Ed. Infobase Publishing, 78-82.

Kierkegaard, Søren. (1974). Bolest na smrt. Beograd: Ideje.

Kordić, Radoman. (2000). Očajanje. Beograd: Filip Višnjić.

Симион, Еуђен. (2016). Румунски егзистенцијализам и европска метафизика: четири субјективна филозофа који желе да обнове румунску културу и један књижевни критичар као негатор који 1943. открива театар апсурда на румунском језику : Мирча Елијаде, Емил Чоран, Константин Нојка, Еуђен Јонеску и Мирча Вулканску. Београд: Филип Вишњић.

Sioran, Emil. (1989). Suze i sveci. Novi Sad: Bratstvo Jedinstvo.

Сиоран, Емил. (1999). О незгоди бити рођен. Београд: Миодраг Шупут.

Сиоран, Емил. (2000). Черечење. Београд: Миодраг Шупут.

Сиоран, Емил. (2001). Крик безнађа. Подгорица: Октоих.

Sioran, Emil. (2004). Kratak pregled raspadanja. Beograd: Tisa.

Spinoza, Baruh. (1959). Etika III. Beograd: Kultura.

Scanlan, Tom. (2007). „Tom Scanlan on Family and Psyche“, Bloom's Guides: The Glass Menagerie. Harold Blood Ed. Infobase Publishing, 82-86.

Murphy, Brenda. (2014). The Theater of Tennessee Williams. Bloomsbury Publishing Plc.

From, Erih. (2016). Bekstvo od slobode. Beograd: Nova knjiga plus; Podgorica: Nova knjiga.

From, Erih. (2018). Čovek za sebe. Beograd: Nova knjiga plus; Podgorica: Nova knjiga.

Cardullo, Bert. (2007). "The Blue Rose of St. Louis: Laura, Romanticism, and The Glass Menagerie", Bloom's Modern Critical Views: Tennessee WilliamsUpdated Edition, Harold Bloom Ed. Infobase Publishing, 65-77. 


\title{
Boban Trifunović
}

\section{THE DESPERATION IN THE GLASS MENAGERIE}

\begin{abstract}
Summary
Tennessee Williams' The Glass Menagerie, as we have attempted to prove, is a work that is, primarily, permeated by desperation. It is a work in which acts of the Wingfield family are, almost entirely, determined by an unfortunate event that took place in the family's distant past. That event is, of course, Mr. Wingfield's departure, his falling in love with long distances. The plague of desperation spread where it was possible, so it spread throughout the Wingfield's family life and started to take over member by member, each in their own way. Tom managed to face the desperation in a variety of ways, to hold the line, so to speak, by trying to elevate himself above it and forget. However, his efforts were futile, as his mother's - and especially his mother's - and sister's whims and ways wouldn't let him be; wouldn't let him forget what he was facing every single day, primarily, the inability to do what he truly wanted to. Finally, Tom gave in to the darkness, to depression, deciding to leave the family, as his father did, years ago, all due to despair. To put all of these premises together, and provide them with a proper interpretation, we have relied on theoretical conceptions of Radoman Kordic and Emil Cioran. Also, we have relied on the work of Erich Fromm to support the idea that Tom Wingfield's desperation not only motivated him to relive his memories but that it is also, to a great extent, derived from the frustration of his attempts to succeed in the psychological process of individuation.
\end{abstract}

Key words: Desperation, Individuation, Memory, Emil Cioran, Radoman Kordic, Erich Fromm. 